\title{
Imports from the Eastern Mediterranean Region in the Roman Military Camp of León (Spain)
}

\author{
By Ángel Morillo*, Rui Morais ${ }^{\dagger} \mathcal{E}$ Rosalía Durán Cabello
}

\begin{abstract}
Archaeological interventions in the last few decades in the city of León, where the Legio VI Victrix and the Legio VII Gemina were located during the Early Roman Empire, have uncovered a considerable amount of Roman pottery. Among these findings, particularly noteworthy are some Eastern Mediterranean amphorae and an important set of glazed pottery from Asia Minor workshops. Analyses of the set reveal the basic products that were habitually consumed in the fortress, in particular, Eastern Mediterranean wines, and prestigious products such as glazed pottery, particularly two skyphoi that present a curious iconographic motif related to the trial of Orestes.
\end{abstract}

\section{Introduction}

Archaeological interventions carried out over the last few decades in several Roman legionary camps located in the north of the Iberian Peninsula (Astorga, León, Herrera de Pisuerga) have recovered an enormous amount of archaeological materials. They have served to gradually reconstruct the chronostratigraphy of these centres during Roman times, as well as their patterns of circulation and pottery supply (Figure 1).

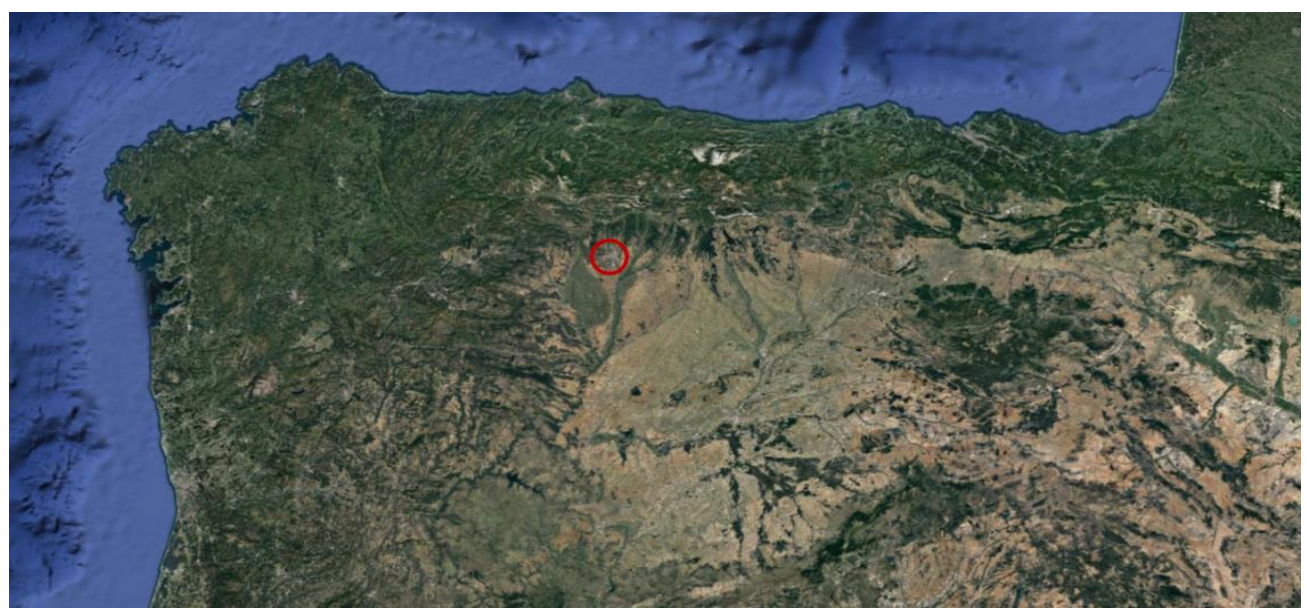

Figure 1. Location of León

Source: Google Earth.

*Professor, Complutense University, Spain.

tProfessor, Universidade do Porto, Portugal.

†Professor, Complutense University, Spain. 
One of the biggest novelties in Spanish Roman military archaeology in recent years has been the progress in the knowledge about the military settlements in the city of León. ${ }^{1}$ León is settled in the smooth hillock located in the watershed between the Bernesga and the Torío rivers. It is a shelf, the last terrace formed by fluvial activity, which slightly dominate the river banks. In fact, the site where the modern town is situated, a genuine crossroad between the table-land plateau and the León central mountain range, offered topographic and spatial conditions with a high strategic value which was not unnoticed by the Romans.

However, the archaeological interventions carried out by V. García Marcos between 1997 and 1999 of a vast plot against the inner face of the north of the Late Roman wall, very close to the porta decumana of the camp of the legio VII has provided conclusive evidence about the features of the beginnings of the Roman presence in the city of León. Beneath the fortress of legio VII gemina the remains of two earlier legionary camps has been recognized. The first legion that occupied the camp was the Legio VI Victrix, of which we know two successive camps: León I, founded around the turn of the Millennium, and León II, built at the beginning of the reign of Tiberius (15/16 AD). ${ }^{2}$

Although little is known of León I's layout, its defensive system was of the agger type, in earth and timber. Its fossa (outer ditch) had a V-type profile, whose vallum was of the box rampart type, consisting of two wooden facades reinforced with vertical stakes. The second camp, León II, 20 Ha and rectangular in shape with rounded corners, practically identical to that later legionary fortress of Legio VII Gemina, presents an agger formed by two converging walls about $4 \mathrm{~m}$ wide at their base, made with caespites. ${ }^{3}$

1. Victorino García Marcos, "Novedades acerca de los campamentos romanos de León" (News about the Roman camps of León), in Arqueología Militar Romana en Hispania (Roman Military Archeology in Hispania), Annexes of Gladius 5, coord. Ángel Morillo (Madrid: Polifemo y CSIC, 2002).

2. García Marcos, "Novedades acerca de los campamentos romanos," 172-177; Ángel Morillo, "Investigación científica y arqueología urbana en la ciudad de León" (Scientific research and urban archeology in the city of León), in Hispaniae urbes. Investigaciones arqueológicas en ciudades históricas (Hispaniae urbes. Archaeological research in historic cities), ed. José Beltrán and Oliva Rodríguez (Sevilla: Univ. Sevilla, 2012), 227-228; Morillo, "Cerámica romana en el campamento de León durante el Alto Imperio: importación vs. Producción local" (Roman pottery in the Leon camp during the High Empire: import vs. local production), in Cerámicas de época romana en el Norte de Hispania y en Aquitania. Producción, comercio y consumo entre el Duero y el Garona (Roman era ceramics in northern Hispania and in Aquitaine. Production, trade and consumption between the Duero and the Garonne), ed. Ana Martínez Salcedo, Milagros Esteban, and Enrique Alcorta (Madrid: La Ergástula, 2015).

3. Morillo and García Marcos, "Legio (León). Introducción histórica y arqueológica" [Legio (Leon). Historical and archaeological introduction], in Los campamentos romanos en Hispania (27 a. C.-192 d. C.). El abastecimiento de moneda [The Roman camps in Hispania (27 $B C-192$ AD). Currency supply], Annexes of Gladius 9, coord. Mª Paz García-Bellido 
Around 74/75 AD, a new unit was installed in the old Legio VI Victrix settlement in León. The Legio VII Gemina, officially founded on $10^{\text {th }}$ June 68 AD in Clunia (province of Tarraconensis) and refounded after the civil wars of 6869 AD as VII Gemina, built a new camp (León III) with structures in stone, dismantling partially the previous constructions. From this moment, León became the permanent base of operations of this unit throughout the Empire. The excavations carried out over the last twenty years in the urban centre have revealed many aspects of the camp, which follows the canonical rectangular layout with rounden corners and four large gates on each side.

The wall of the Flavian legionary fortress, $1.80 \mathrm{~m}$ and $2 \mathrm{~m}$ in width, and boosting an exterior facade in opus vitatum, was composed of sandstone blocks and inner filler compounds of excellent quality, reaching in one of its sections approximately $4.25 \mathrm{~m}$ in height. ${ }^{4}$ The back wall, flanking the Flavian camp, was built by dismantling the outer half of the vallum of the previous camp. The ditches of the Julio-Claudian camp on the outside of the walled perimeter were kept, following the usual model of Roman encampments. The defensive system was completed with inner towers and four double gates, also flanked by towers. The porta principalis sinistra and part of the still preserved porta praetoria have been excavated. ${ }^{5}$

Gradually, the excavations reveal details about the sanitary infrastructures, the water supply, the internal arrangement and the inner buildings of the camp, as well as the constructions corresponding to the two military vici. ${ }^{6}$

At the end of the $3^{\text {rd }}$ century or beginning of the $4^{\text {th }}$, during the Tetrarch period, a new wall was built adjacent to the external façade of the Early Imperial defences. The new construction was reinforced with semicircular towers $8.25 \mathrm{~m}$ in diameter placed every $15 \mathrm{~m}$. In the new construction, an abundant

(Madrid: CSIC and Polifemo, 2006), 231-232; Morillo, "Investigación científica y arqueología urbana," 227-228.

4. Morillo, 235-236.

5. García Marcos, "Novedades acerca de los campamentos romanos," 189-195; Morillo and García Marcos, "The defensive system of the legionary fortress of VII gemina at León (Spain): The porta principalis sinistra," in Limes XIX. Proceedings of the XIXth International Congress of Roman Frontier Studies, ed. Zsolt Visy (Pécs: University of Pécs, 2005), 237; Morillo and Rosalía Durán Cabello, "La puerta meridional del recinto amurallado de la ciudad de León (siglos I-XIII). Análisis estratigráfico e interpretativo de una nueva evidencia constructiva" [The southern gate of the walled enclosure of the city of León (1 $1^{\text {st }}$ $13^{\text {th }}$ centuries). Stratigraphic and interpretive analysis of new constructive evidence], Arqueología de la Arquitectura 14 (2017): 1-26.

6. Morillo, "Investigación científica y arqueología urbana"; Morillo, Rui Morais, and Durán Cabello, "Cerámica vidriada romana en los contextos altoimperiales del campamento de León (España)" [Roman glazed ceramics in the high imperial contexts of the León camp (Spain)], Saguntum [in press]. 
amount of materials was reused, among which the epigraphs stand out. The wall is about $7 \mathrm{~m}$ in width, including the width of the old Flavian wall (Figure 2). ${ }^{7}$

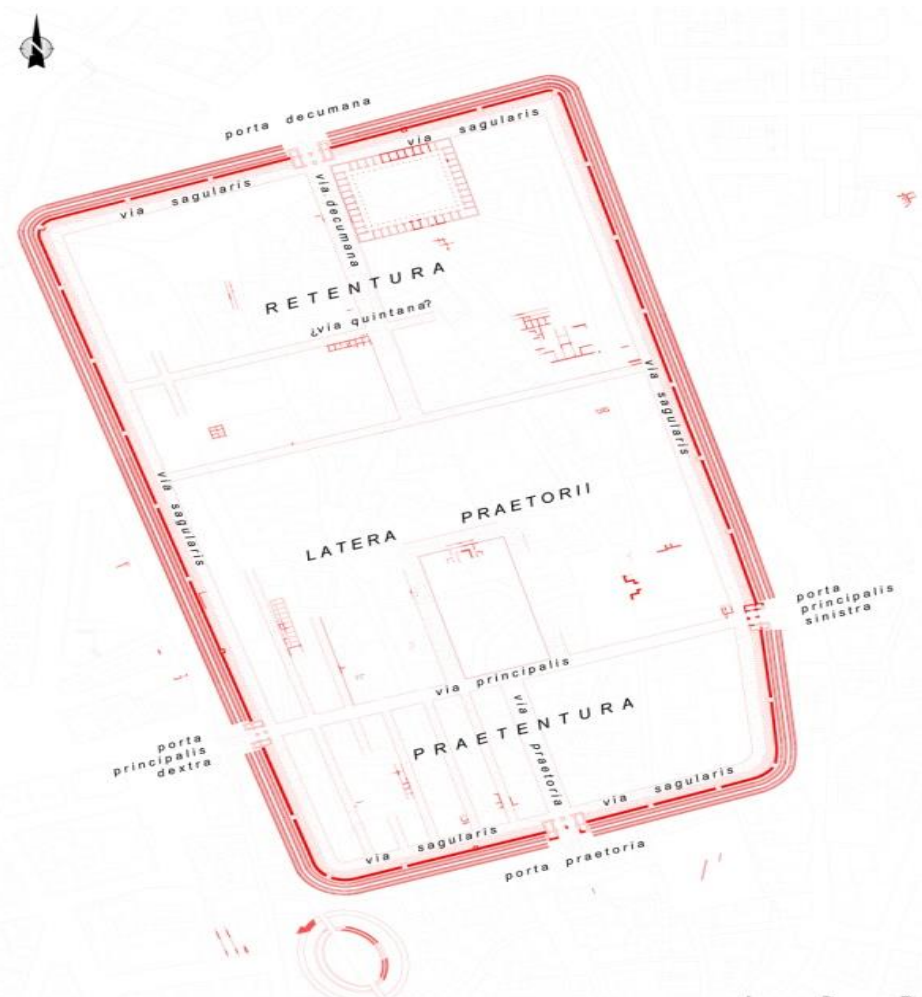

Figure 2. The Flavian Legionary Fortress of Legio VII Gemina at León Note: Below lies the remains of the previous two camps of Late Augustan and JulioClaudian times, belonging to Legio VI Victrix.

The stratigraphic studies carried out in the León camps establish several very well-defined chronological limits. We can observe, through the analysis of the material culture, a complete sequence of occupation. The presence of imported earthenware, in particular fine tableware, such as terra sigillata, oil lamps, thinwalled pottery and glazed pottery, as well as containers or vessels for the transportation of products, are fundamental for the dating of the different phases of occupation. ${ }^{8}$ In addition to the Italic and Gallic products and those from other

7. García Marcos, Durán Cabello, and Morillo, "La muralla tetrárquica de Legio: aproximación al conocimiento de su sistema constructivo" (The Tetrarchic wall of Legio: approach to the knowledge of its construction system), in Murallas de Ciudades Romanas en el Occidente del Imperio (Walls of Roman Cities in the Western Empire), ed. Antonio Rodríguez Colmenero and Isabel Rodá (Lugo: Diputación Provincial de Lugo, 2007).

8. Morillo and García Marcos, "Legio (León): cronologías estratigráficas" [Legio (León): stratigraphic chronologies], in Los campamentos romanos en Hispania (27 a. C.-192 d. C.). El abastecimiento de moneda [The Roman camps in Hispania (27 BC-192 AD). Currency supply], Annexes of Gladius 9, coord. M ${ }^{\mathrm{a}}$ Paz García-Bellido (Madrid: CSIC and Polifemo, 2006), 
regions of Hispania, such as Baetica and the Catalonian coast, there is a significant number of products from the Eastern Mediterranean. ${ }^{9}$ This fact is particularly remarkable, especially if we take into account that the camps were located in inland areas, more than $200 \mathrm{~km}$ away from maritime-river routes. Also, these Eastern products, represented by high-quality, expensive wines, were delivered upon order from a military elite, who appreciated them more than quality productions of Italic origin. The purpose of this article is to examine these imports of Eastern origin.

Almost all specimens come from landfill levels made up of earth and materials deposited in primary detrital trenches, later transported intentionally to level and accommodate the natural topography of certain sectors, particularly on the slopes situated at $\mathrm{O}$ and $\mathrm{E}$ of the hill where the camp is located. They are thus secondary deposits for the amortisation of materials, with the degree of distortion that can be introduced in the dating of the materials, since they are post quem dates. $^{10}$

\section{The Amphorae}

The more than three hundred fragments (313) of amphorae found in León, corresponding to around 231 fewest possible number of amphorae (index Minimum Number of Individuals=NMI) of 30 distinct forms, serve to analyse the

292-298; Morillo, "Cerámica romana en el campamento de León"; Morais and Morillo, "La terra sigillata hispánica altoimperial en los contextos de consumo del noroeste peninsular: Bracara Augusta y Legio" (The high-imperial Hispanic sigillata terra in the consumption contexts of the peninsular northwest: Bracara Augusta and Legio), in Terra sigillata Hispánica. 50 años de investigaciones (Terra sigillata Hispanic. 50 years of research), ed. Maria Isabel Fernández García, Pablo Ruiz Montes, and $\mathrm{M}^{\mathrm{a}}$ Victoria Peinado (Roma: Quasar, 2015); Morillo, Morais, and Rosario García Giménez, "Análisis mineralógico, físico y químico de ánforas tipo Dressel 28 y jarras en cerámica común del campamento romano de León" (Mineralogical, physical and chemical analysis of Dressel 28 amphorae and common ceramic jugs from the Roman camp of León), in Archaeoanalytics. Chromatography and DNA analysis in Archaeology, ed. Morais, Cesar Oliveira, and Morillo (Esponsende: Esposende City Council, 2015); Morillo, Morais, and Durán Cabello, "Cerámica vidriada romana."

9. Morillo and Garcia Marcos, "Importaciones itálicas en los campamentos romanos del norte de Hispania durante el periodo augusteo y julioclaudio" (Italic imports in the Roman camps of northern Hispania during the August and July claudio periods), in Rei Cretariae Romanae Fautores. Acta 38 (Abingdon: RCRF, 2003); Morillo, "Abastecimiento y producción local en los campamentos romanos de la región septentrional de la península ibérica" (Local supply and production in the Roman camps of the northern region of the Iberian Peninsula), in Arqueología Militar Romana en Hispania: Producción y abastecimiento en el ámbito militar (Roman Military Archeology in Hispania: Production and supply in the military field), ed. Morillo (León: Universidad de León, 2006).

10. Morais and Morillo, "La terra sigillata hispánica altoimperial," 231-232. 
products that were habitually consumed in the camps established in this region, in particular the wines and their derivatives, as well as olive oil and fish preparations. The analysis of the manufacture, allied to typological characterisation, has identified specimens of very different origins (Table 1 and Figure 3).

\begin{tabular}{|c|c|c|c|}
\hline Amphorae & NF & MNI & $\%$ \\
\hline Dressel 1 (Campanian/Lacio) & 2 & 2 & 0,87 \\
\hline Dressel 2-4 (Campanian/Lacio) & 18 & 12 & 5,19 \\
\hline Forlimpópoli/Agora K 114 (Italic) & 2 & 1 & 0,43 \\
\hline Italic (ind.) & 3 & 3 & 1,30 \\
\hline Late-rodian/Camulodunum 184 (Eastern) & 19 & 13 & 5,63 \\
\hline Dressel 5 (Eastern, Cos) & 5 & 4 & 1,73 \\
\hline Pseudo-Koan (Eastern) & 6 & 5 & 2,16 \\
\hline Eastern (Ind.) & 1 & 1 & 0,43 \\
\hline Dressel 2-4 (Galic) & 4 & 4 & 1,73 \\
\hline Gauloise 2 (Galic) & 2 & 2 & 0,87 \\
\hline Gauloise 3 (Galic) & 1 & 1 & 0,43 \\
\hline Gauloise 4 (Galic) & 1 & 1 & 0,43 \\
\hline Dressel 28 (Galic) & 1 & 1 & 0,43 \\
\hline Galic (ind.) & 2 & 2 & 0,87 \\
\hline Pascual 1 (Tarraconensis) & 3 & 3 & 1,30 \\
\hline Dressel 2-4 (Guadalquivir) & 25 & 14 & 6,06 \\
\hline Haltern 70 (Guadalquivir) & 13 & 11 & 4,76 \\
\hline Indeterminada Cadiz & 27 & 22 & 9,52 \\
\hline Dressel 2-4 (Cadiz) & 3 & 3 & 1,30 \\
\hline Oberaden 83 (Guadalquivir) & 11 & 9 & 3,90 \\
\hline Dressel 20 (Guadalquivir) & 12 & 9 & 3,90 \\
\hline León I/Dressel 28 similis & 59 & 36 & 15,58 \\
\hline Dressel 16 (Galic) & 4 & 3 & 1,30 \\
\hline Fréjus/Lenzbourg (Galic) & 2 & 2 & 0,87 \\
\hline Dressel 7-11 (Cadiz) & 18 & 11 & 4,76 \\
\hline Dressel 7-11 (Cadiz) & 1 & 1 & 0,43 \\
\hline Mañá C2b/Ramón T-7.4.3.3 (Guadalquivir) & 1 & 1 & 0,43 \\
\hline Dressel 12 (Guadalquivir) & 6 & 5 & 2,16 \\
\hline Dressel 7-11 (Guadalquivir) & 7 & 7 & 3,03 \\
\hline Indeterminada Guadalquivir & 37 & 27 & 11,69 \\
\hline Lusitanian ovoid type amphorae y Dressel 14 & 9 & 8 & 3,46 \\
\hline Richborough 527 (Italic) & 1 & 1 & 0,43 \\
\hline Lomba do Canho 67/Sala 1 (Guadalquivir) & 3 & 3 & 1,30 \\
\hline Rías Bajas & 4 & 3 & 1,30 \\
\hline Total & 313 & 231 & 100,00 \\
\hline
\end{tabular}

Table 1. Quantity (Total and Minimum Number of Individuals) and Percentages Calculates Respect NMI of Amphorae of Legionary Fortress of León (Summary) 


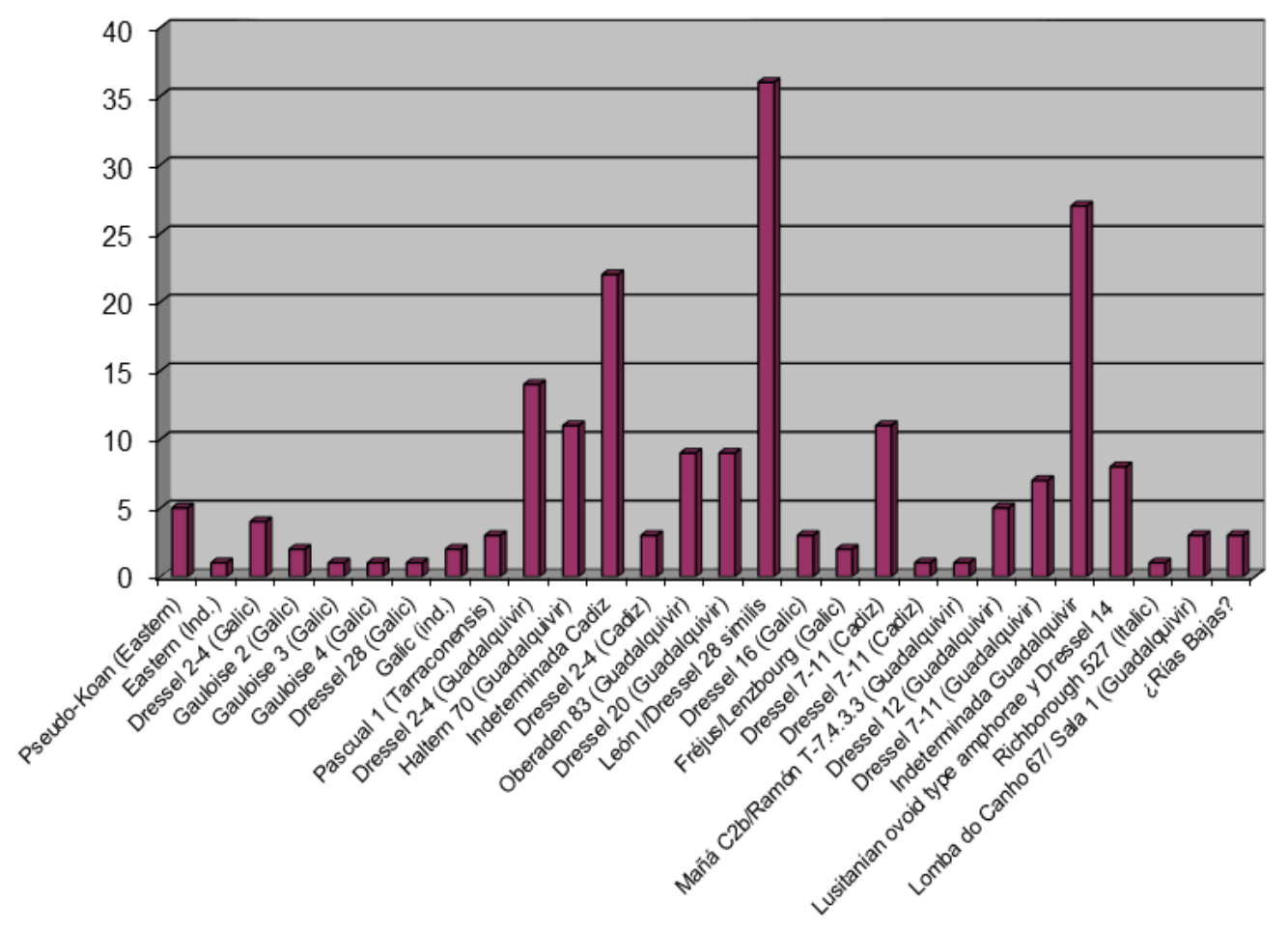

Figure 3. Quantity (Total and Minimum Number of Individuals) and Percentages Calculates Respect NMI of Amphorae of Legionary Fortress of León (Diagram)

As can be seen in Table 2 and Figure 4, Hispanic imports of Baetic origin predominate in León (more than 50\%), with around 37.2\% from the Guadalquivir valley and $16 \%$ from the coast of Cadiz. Next in importance we have productions coming from the Eastern Mediterranean, accounting for 10\%, and of Italic origin with $8.2 \%$. Gaulish amphorae are less numerous, accounting for $6.9 \%$, despite great formal variability and their rarity or even absence in Iberian contexts, and the Lusitanian and Tarragona productions, with only 3.5\% and $1.3 \%$, respectively. But one of the most interesting aspects of the León amphorae set is the presence of local and regional productions, summing about $16.98 \%$, namely $15.58 \%$ flatbottomed amphorae, and indeterminate forms, only represented by $1.30 \%$, whose production can possibly be attributed to the coastal area of the Rias Baixas, in Galician coast. ${ }^{11}$

11. Morillo and Morais, Ánforas de los campamentos romanos de León. Un modelo de abastecimiento militar entre el periodo augusteo y los inicios del siglo II d. C. (Amphoras of the Roman camps of León. A military supply model between the August period and the beginning of the second century AD. C), Annexes Spanish Archive of Archeology (Madrid: CSIC, in press). 


\begin{tabular}{|l|c|c|}
\hline Production areas & MNI & $\mathbf{\%}$ \\
\hline Eastern & 23 & 10,0 \\
\hline Italic & 19 & 8,2 \\
\hline Gaulish & 16 & 6,9 \\
\hline Baetica (Cadiz) & 37 & 16,0 \\
\hline Baetica (Guadalquivir) & 86 & 37,2 \\
\hline Tarraconensis & 3 & 1,3 \\
\hline Lusitanian & 8 & 3,5 \\
\hline Local/Regional & 39 & 16,9 \\
\hline Total & $\mathbf{2 3 1}$ & $\mathbf{1 0 0}$ \\
\hline
\end{tabular}

Table 2. Quantity (NMI) and Ratio of Amphorae Production Areas (Summary)

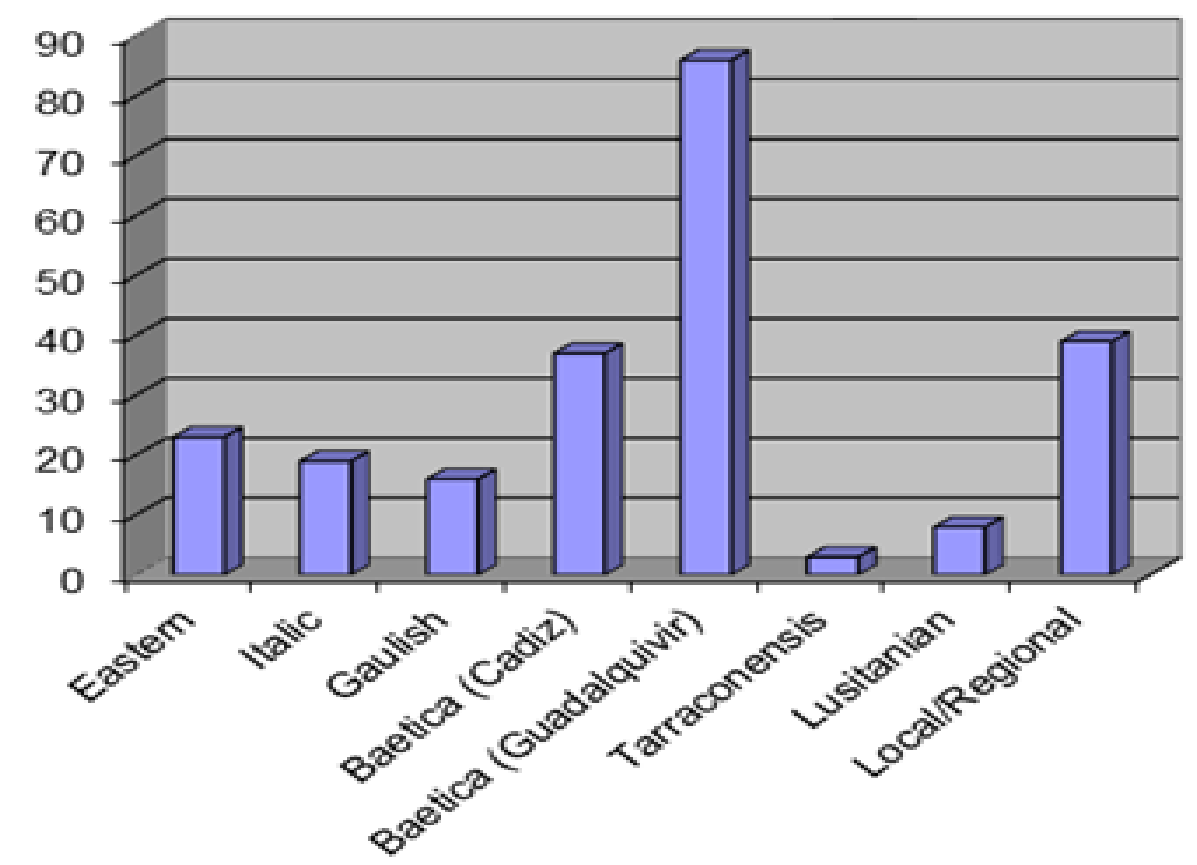

Figure 4. Quantity (NMI) and Ratio of Amphorae Production Areas (Diagram)

With regard to the products transported, as we have already mentioned and as we can see on Table 3 and Figure 5, wine and its derivatives predominate, with $32.90 \%$. They are followed by olive oil, with $23.38 \%$, and fish sauces, with $18.61 \%$. However, this number may distort the image of imports. In fact, imported olive oil from Baetica only reaches $7.96 \%$, whereas the rest corresponds to local flat-bottom amphorae for the internal distribution of olive oil (15.58\%), a supply mechanism we have already addressed. ${ }^{12}$

12. Morillo, Morais, and García Giménez, "Análisis mineralógico"; Morillo and Morais, Ánforas de los campamentos romanos de León. 
Only one specimen was reported which possibly carried alum, a Richborough 527 type amphora. These multi-purpose vessels, which could be used as containers for a wide variety of products, amount to $2.60 \%$. Finally, we must mention the indeterminate products, represented by $22.08 \%$ of the total.

\begin{tabular}{|l|c|c|c|}
\hline Quantity and products transported & NF & MNI & $\mathbf{\%}$ \\
\hline Wine and its derivatives & 106 & 76 & 32,90 \\
\hline Olive oil & 82 & 54 & 23,38 \\
\hline Fish sauces & 51 & 43 & 18,61 \\
\hline Alumbre & 1 & 1 & 0,43 \\
\hline Multi-purpose vessels & 7 & 6 & 2,60 \\
\hline Indeterminate products & 66 & 51 & 22,08 \\
\hline Total & $\mathbf{3 1 3}$ & $\mathbf{2 3 1}$ & $\mathbf{1 0 0 , 0 0}$ \\
\hline
\end{tabular}

Table 3. Quantity and Products Transported (Summary)

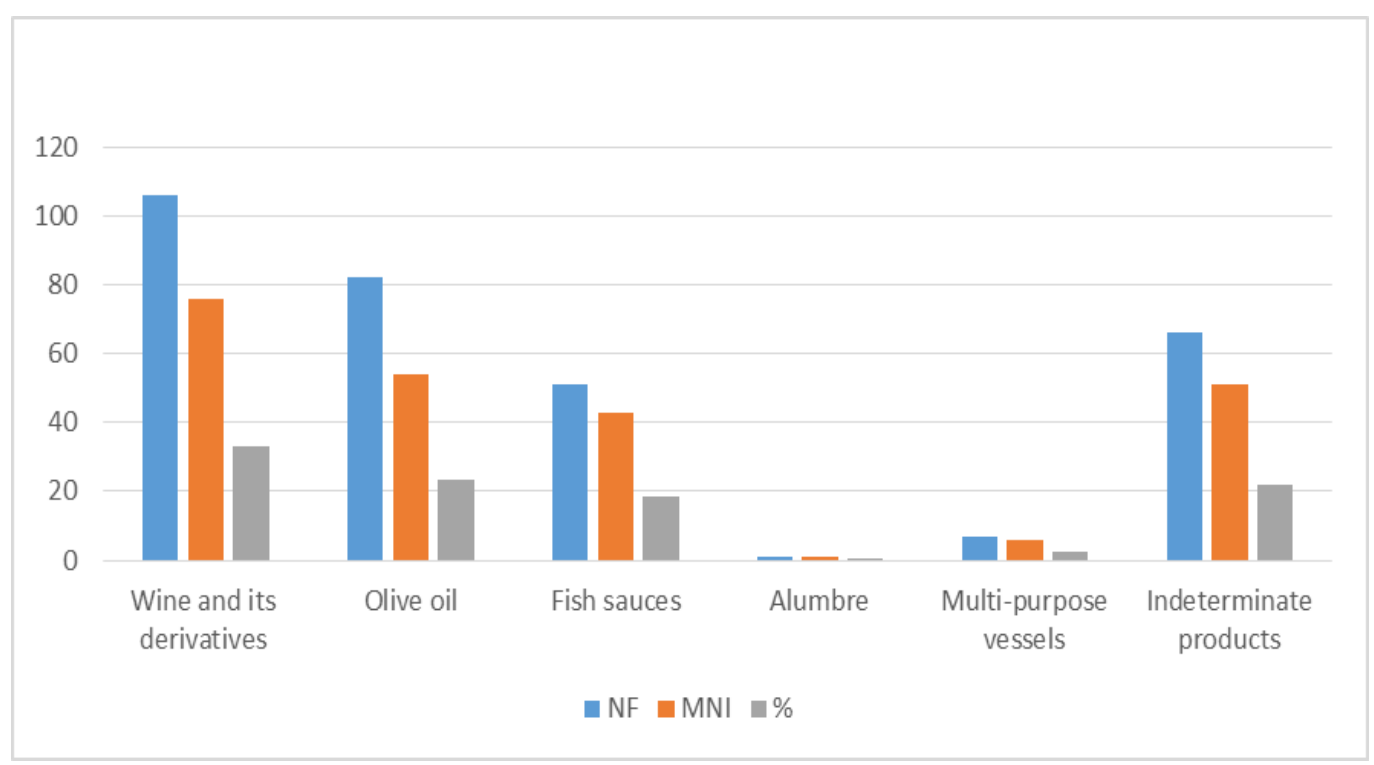

Figure 5. Quantity and Products Transported (Diagram)

In this study, the focus will fall particularly on products from the Eastern Mediterranean. These products correspond, as we have already mentioned, to the famous wines transported in the late Rhodian/Camulodunum 184 (Figure 6, no 13), Dressel 5 (Figure 6, $n^{\circ}$ 4) and Pseudo-Koan (Figure 6, no 5) amphorae, well documented in other archaeological sites in the north-east of the Iberian Peninsula since the Augustan era, particularly in Astorga ${ }^{13}$ and Lugo. ${ }^{14}$ In León,

13. César Carreras Monfort and Piero Berni Millet, "Anforas" (Amphorae), in Astorga IV. Lucernas y ánforas (Astorga IV. Lucernas and amphorae), ed. Ma Teresa Amaré (León: Universidad de León, 2003), 646, 648-649. 
these amphorae are represented by a lot of thirteen amphorae of the late Rhodian/Camulodunum 184 type, followed by the Pseudo-Koan type, with four specimens, and Dressel 5, also with four specimens (Figure 6).

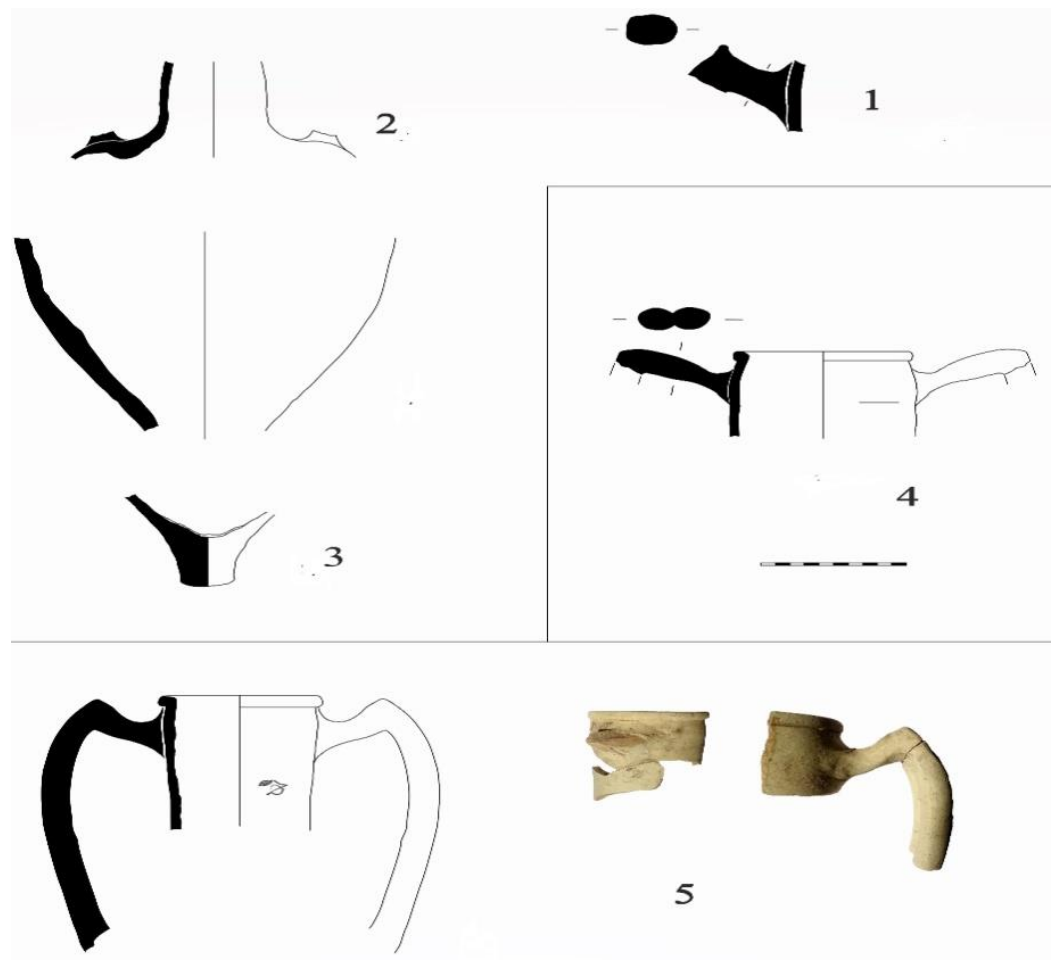

Figure 6. Eastern Roman wine amphorae (Late Rodian/Camulodunum 184, $n^{0}$ 1-3; Dressel 4, $n^{-0}$ 4; Pseudo-Koan, $n^{-}$5)

Figure 7 shows comparative graphs of the amphorae supply in the Roman camp of Léon taking into consideration the producing regions and chronological periods. We must highlight the very strong presence of Eastern amphorae during the Late Augustan period, which coincides with the foundation of the León camp. In this period, Eastern wine (transported in Late-Rodian, Pseudo-Koan and Dressel 5 amphorae) represents $20 \%$ of all amphorae supply, even doubling Italian imports. This predominance of luxury imports of Eastern wine over Italic one, both intended for the military elite, will continue throughout the following periods even though their amounts will reduce significantly during Tiberian $(6.7 \%)$, Early Claudian-Neronian $(7.14 \%)$ and Late Neronian-Flavian period $(5.66 \%)$.

14. Carreras Monfort and Morais, "Las ánforas de Lucus Augusti (Lugo)" [The amphorae of Lucus Augusti (Lugo)], in Ánforas romanas de Lugo (Roman amphorae of Lugo), ed. Carreras Monfort, Morais, and Enrique González Fernández (Lugo: Concello de Lugo, 2011), 56-59. 


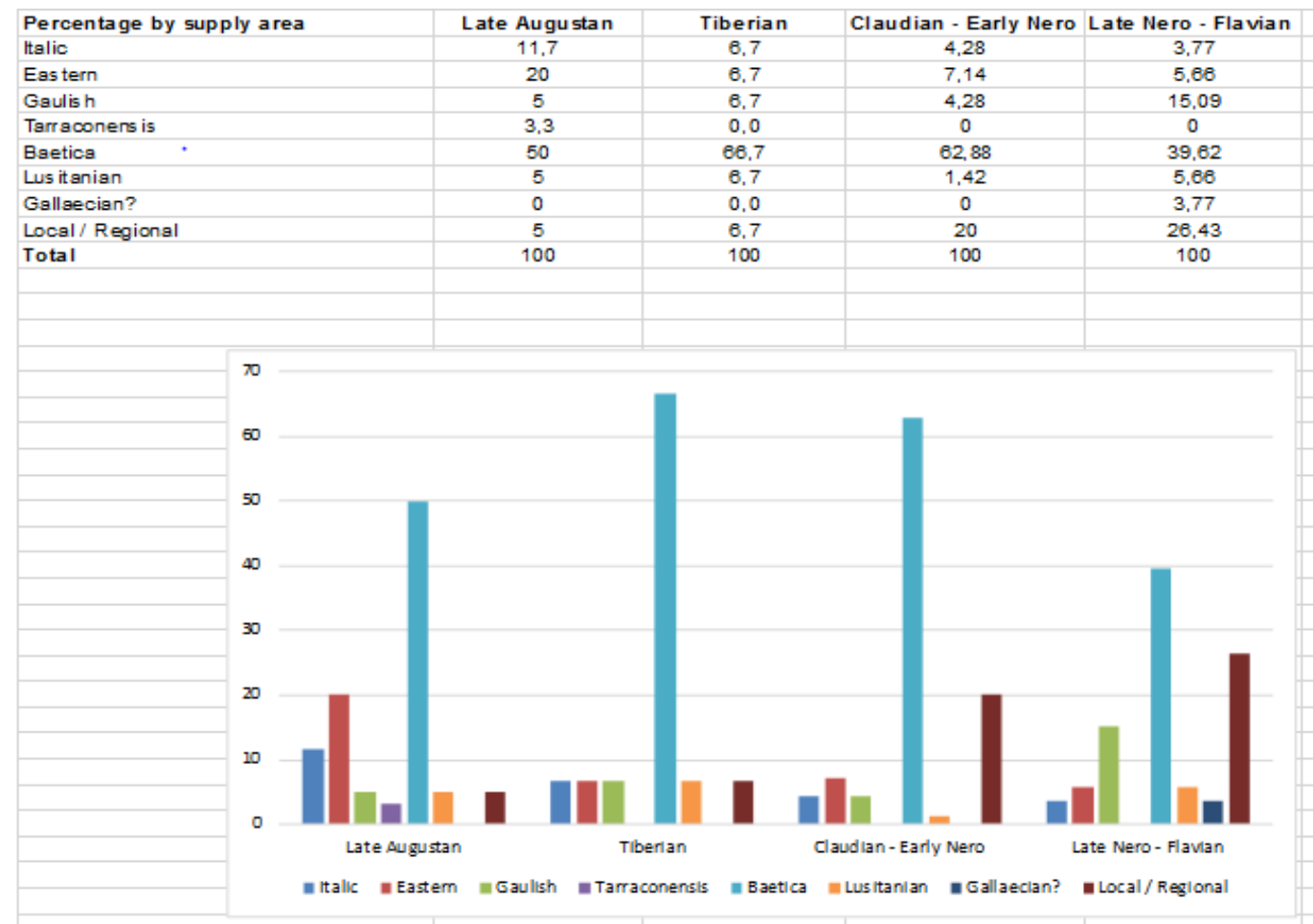

Figure 7. Comparative Diagrams of the Amphoric Supply to the Camp of León by Producing Regions and Chronological Periods

The late Rhodian/Camulodunum 184 amphorae date mostly from Late Augustan contexts associated with the first Legio VI Victrix camp (Casa Pallarés, UE 122, 131, 132, Edificio Botines, UE 150, UE 4070 of Santa Marina). Some also date from the Tiberian period (Casa Pallares, EU 149) and from the mid-first century AD (UE 9 and 11 of San Pedro, UE 4045 of Santa Marina), coinciding with the second camp of Legio VI. Vestiges suggest their presence until the end of the first century AD, since only three late Rhodian amphorae were found in the Late Neronian period (UE 225 of Casa Pallares, UE 128 of Edificio Botines, UE 4019 of Santa Marina), which came to be clearly associated with the Legio VII Gemina camp.

Among the specimens of the Pseudo-Koan type, particularly noteworthy is a fragment that still retains a titulus in which the Greek letter $\Phi$ can be read, which, according to the Cypriot modius, is equivalent to 9.8 litres. Similar to the previous form, most of the specimens were collected in stratigraphic units from the Late Augustan period (Era of transition-15 AD) (UE 122 Casa Pallarés, UE 158 and 168 Calle de la Rua 27-31). Some items were found in later strata dating from the mid-first century AD (UE 9 San Pedro, UE 138 Calle de la Rua 27-31).

Imports of this kind were interrupted during the Neronian period, and did not reach the Flavian contexts.

Dressel 5 specimens also come from different excavation sectors (Casa Pallarés, Edificio Botines and Calle de la Rua 27-31). However, the period of use 
in León is much more restricted. Except for a fragment from the last intervention found in an area interfered with during the medieval period (UE HY-136), the remaining specimens come from the Late Augustan UE (Era of transition-15/16 AD), associated with the first León camp (500C-D of Casa Pallares, UE 131 Edificio Botines, UE 166 and 306 Calle de la Rua, 27-31). After Tiberius' rise to power, they disappear in the stratigraphies of the León camp. ${ }^{15}$

\section{Glazed Pottery}

Ceramic vessels with a vitreous coating were not particularly abundant in Roman times, since their production required highly developed technology. Manufacturing with this technique began shortly before the mid-first century BC in the workshops of Asia Minor, such as Mytilene, Perge, Tarsus, around Smyrna and somewhere in south-western Anatolia. ${ }^{16}$ Although these productions were discovered in the mid-twentieth century, ${ }^{17}$ they were only categorised a few years later by Gabelmann ${ }^{18}$ and Hochuli-Gysel, ${ }^{19}$ whose work had a much greater impact. The majority of the roman glazed pottery belong to tableware forms, specifically vessels for drinking and serving liquids. These forms mimic the most common types of metal tableware, such as the skyphos and kantharos, as well as goblets. Other forms, such as jars, are less common.

Hochuli-Gysel carefully studied the inspiration of this morphological repertoire in silver and bronze tableware shapes, a form of imitation that was accentuated by the brilliant glaze of their surfaces with shades close to the metallic originals. A comparison with the great treasures of silver tableware, such as the Hildesheim and Boscoreale, shows their great formal similarity, which can also be found in some decorations. This researcher further points out the custom (as we have seen in the silver treasures) of households having two identical pieces, made from the same mould, as in the case of glazed pottery, which poses interesting questions regarding the customs related to the festivities of the middle

15. Morillo and Morais, Ánforas de los campamentos romanos de León.

16. Anne Hochuli-Gysel, Kleinasiatische glasierte Reliefkeramik (50 v. Chr. Bis 50 n. Chr.) und ihre oberitalischen Nachamungen [Asia Minor glazed relief ceramics (50 BC to $50 A D$ ) and their Upper Italian aftermath], Acta Berniensia 7 (Bern: Verlag Stämpeli and CIE AG, 1977), 107-122, 309-311.

17. Hetty Goldman, Excavations at Gözlü Kule, Tarsus, I, The Hellenistic and Roman Period (Princeton: Princeton Press, 1950), 146; Frances Folin Jones, Excavations at Gözlü Kule, Tarsus I. The Hellenistic and Roman Period (Princeton: Princeton Press, 1950), 193.

18. Heinrich Gabelmann, "Zur hellenistisch-römischen Bleiglasurkeramik in Kleinasien" (On the Hellenistic-Roman lead glaze ceramic in Asia Minor), Journal of Deustchen archäoliguschen Instituts 89 (1974): 260-307.

19. Hochuli-Gysel, Kleinasiatische glasierte Reliefkeramik. 
and upper strata of Roman society. ${ }^{20}$ It is significant that silver and bronze metal vessels reached their highest quality and refinement precisely in the time of Pompey. ${ }^{21}$

A few years ago, F. F. Jones suggested these vessels were related with the rhosica vasas Cicero mentioned in his epistole Ad Atticum, ${ }^{22}$ written to his friend Atticus when the orator was governor of Cilicia in $51-50 \mathrm{BC}^{23}$ Cicero alludes to the glazed aspect of the productions made in the port of Rhossus, near Tarsus. The coincidence of this allusion with the moment when these productions appear in areas of Asia Minor is an argument in favour of this interesting hypothesis. ${ }^{24}$

Different analyses have confirmed the features of the clays and glazes from these Asia Minor specimens. ${ }^{25}$ Glazed vessels spread throughout the Mediterranean from the manufacturing centers on the coast of Asia Minor, reaching Italy and the western provinces from the mid-first century BC. They

20. Hochuli-Gysel, "La cerámique à glaçure plombifère d'Asie Mineure e du basin Mediterranéan oriental (du Ier s. av. J.-C. au Ier s. ap. J.-C.)" [The lead-glazed ceramics of Asia Minor and Eastern Mediterranean Basin (1st century BC to 1st century AD)], in Céramiques hellénistiques et romaines: Productions et diffusion en Méditerranée orientale (Chypre, Égypte et côte syro-palestinienne) [Hellenistic and Roman ceramics: Productions and diffusion in the Eastern Mediterranean (Cyprus, Egypt and the Syrian-Palestinian coast)], ed. Francine Blondé, Pascal Ballet, and Jean-François Salles (Lyon: Travaux de la Maison de 1'Orient 35, 2002), 307-309.

21. Lucia Pircio Biroli Stefanelli (Ed.), L'argento dei romani. Vasellame da tavola $e$ d'apparato (The silver of the Romans. Tableware and equipment) (Roma: L'Erma d'Bretshcneider, 1991), 63; Pircio Biroli Stefanelli (Ed.), I Bronzo dei romani. Arredo e suppellettile. Il Metallo: Mito e fortuna nel mondo antico (Bronze of the Romans. Furnishings and furnishings. The Metal: Myth and luck in the ancient world) (Roma: L'Erma d'Bretsheneider, 2008); Morillo, "La cerámica vidriada romana en Hispania" (Roman glazed pottery in Hispania), in Manual de Cerámica romana III. Cerámicas romanas de época altoimperial en Hispania. Cerámica común de mesa, cocina y almacenaje. Imitaciones hispanas de producciones romanas universales (Roman Ceramics Manual III. Roman ceramics from the high imperial era in Hispania. Common ceramic table, kitchen and storage. Hispanic imitations of universal Roman productions), ed. Carmen Fernández Ochoa, Morillo, and Mar Zarzalejos (Alcalá de Henares: MNAR, 2017), 394.

22. VI.1.13

23. Frances Follin Jones, "Rhosica Vasa," American Journal of Archaeology 49, no. 1 (1945): 45-51.

24. Claudia Maccabruni, "Cerámica con invetriatura al piombo" (Cerámica with lead glaze), in Céramiques hellénistiques et romaines II (Hellenistic and Roman ceramics II), ed. P. Léveque and Jean-Paul Morel (Paris: CNRS, 1987), 170.

25. Helen Hatcher, Alexander Kaczmarczyk, Agnès Scherer, and Robin Symonds, "Chemical classification and provenance of some glazed ceramics," American Journal of Archaeology 98, no. 3 (1994): 431-456; Billur Tekkök, Ali Akyol, Yusuf Kadioglu, and Sahinde Demirci, "The importance of archaometric analysis on ceramics from archaeological excavations: the example of Early Roman glazed ware from Tarsus and Troia," in Seres 09. International Ceramic, Glass, Porcelain Enamel, Glaze and Pigment Congress (Eskisehir: Anadolu University, 2009). 
achieved, though, their greatest diffusion during the first half of the first century $\mathrm{AD}$, ceasing production by the middle of this century. Their presence in Western markets led to the establishment of workshops that imitated these vessels and gradually adapted them to new regional fashions, reducing the repertoire of forms and introducing new ones, such as rython, askos and amphoriskoi, along with a less refined and utilitarian repertoire, such as dishes, bowls, plates, jugs, pots, etc.

Although yet to be studied, the abundance of containers of this type and the characteristics of their clays, with abundant volcanic minerals, point to certain manufacturing centres in Campania or Lazio from the end of the first century BC. However, in the following centuries, ${ }^{26}$ the centres are mostly located in the north of Italy, ${ }^{27}$ in Transalpine Gaul, ${ }^{28}$ in the center of Gaul ${ }^{29}$ and in Lazio. ${ }^{30}$

26. Gianluca Soricelli, "Osservazioni intorno ad un crátere in cerámica invetriata da Pompei" (Observations around a crátere in cerámica glazed from Pompeii), Rivista Studi Pompeiani 2 (1988): 248-254; Hatcher et al., "Chemical classification and provenance of some glazed ceramics," 446; Emanuela di Gioia, La ceramica invetriata in area vesubiana (Glazed ceramic in the Vesubian area) (Roma: L'Erma di Bretschneider, 2006), 139-140.

27. Hochuli-Gysel, Kleinasiatische glasierte Reliefkeramik, 137-142.

28. André Desbat, "Céramiques romaines à glaçure plombifère de Lyon et de Vienne" (Roman ceramics with lead glaze of Lyon and Vienne), SFECAG. Congress Proceedings of Toulouse (Marseille: SFECAG, 1986); Desbat, "Céramiques romaines à glaçure plombifère des fouilles de Lyon (Hauts-de-Saint-Just, Rue des Farges, La Solitude)" [Roman ceramics with lead glaze of the excavations of Lyon (Hauts-de-Saint-Just, Rue des Farges, La Solitude)], Figlina 7 (1986): 105-124; Desbat, "Les productions précoces de Céramiques à glaçure plombifère de la Vallée du Rhôhne" (The early productions of ceramics with lead glaze of the Rhôhne Valley), Rei Cretariae Romanae Fautorum, RCRF, Acta 34 (Székesfehérvar: RCRF, 1995), 39-48; Pauline Gohier, Claudio Capelli, and Roberto Cabella, "Les cerámiques à glaçure plombifère en Gaule Méridionale: nouvelles données archéologiques et archéometriques" (The ceramics with lead glaze in southern Gaul: new archaeological and archaeological data), SFECAG. Proceedings of the Autumn Congress (Marseille: SFECAG, 2016); Gohier, Les cerámiques à glaçure plombifere antiques en Gaule méridionale et dans la vallée du Rhône (Ier siècle av. J. C. - IIIe siècle apr. J.-C.) [The ceramics with ancient lead glaze in southern Gaul and in the Rhone Valley (1st century BC - $3^{\text {rd }}$ century AD)], Archeology Roman History, 40 (Drémil Lafage: M. Mergoil Editions, 2018), 65-73.

29. Hugues Vertet, "Recherches sur les glaçures plombifères fabriquées dans le centre de la Gaule" (Research on lead glazes made in the center of Gaul), SFECAG. Congress Proceedings of Toulouse (Marseille, SFECAG, 1986).

30. Archer Martin, "La ceramica invetriata romana: la testimonianza dell'area NE delle terme del Nuotatore ad Ostia" (The Roman glazed ceramic: the testimony of the NE area of the Nuotatore spa in Ostia), in La ceramica invetriata tardoantica e altomedievale in Italia (Late antique and early medieval glazed pottery in Italy), ed. Lidia Paroli (Firenze: All'Insegna del Giglio, 1992); Martin, "Central Italian lead-glazed ware," Rei Cretariae Romanae Fautorum, RCRF, Acta 34 (Székesfehérvar: RCRF, 1997), 302-312; Silvia Lusuardi Siena, and Marco Sannazaro, "Ceramica invetriata" (Glazed ceramics), in Scavi MM3. Ricerche di archeologia urbana a Milano durante la costruzione della linea 3 della Metropolitana 
Analyses of the clays and glazes from items of Asia Minor production ${ }^{31}$ have revealed that these vessels spread throughout the Mediterranean, reaching the Italic Peninsula and the western provinces of the Empire from the middle of the first century $\mathrm{BC}$, with a peak in the first half of the first century $\mathrm{AD}$, ceasing around the middle of this century. These pieces are made from moulds, using highly refined pale, ochre, yellowish and whitish clays, with a few rounded vacuoles. The glazes are light green or emerald on the outside and yellowish on the inner surface, usually shiny and thick. The archaeometric analyses carried out on these specimens confirm that the pieces were subjected to double firing, as is usual in this type of manufacture.

While Roman glazed pottery does not appear to have been very abundant in the Hispanic provinces, research over the past twenty years has shown that these vessels are distributed in small quantities throughout the Peninsula. ${ }^{32}$ For the most part, these materials were found very fragmented or had lost their glaze, which in some cases led them to be confused with medieval vessels. Until a few decades ago, the presence of Roman glazed pottery was considered to be residual in the northern territories of the Iberian Peninsula, since only a few specimens were known, such as those found in Herrera de Pisuerga or Pompaelo. This situation has gradually changed with the most recent findings at Campa Torres, Gijón, Chao Samartín, Numancia, Rosinos de Vidriales and Asturica Augusta, together with oil lamps found in this Asturian capital and in Bracara Augusta. ${ }^{33}$

(MM3 excavation. Urban archeology research in Milan during the construction of the Metro line 3) (Milano: ET, 1991); Marco Biagini, "Ceramica invetriata campano-laziale in Liguria" (Glazed Campania-Lazio ceramics in Liguria), Rivista Studi Liguri LVIII (1992): 131-146; Marco Sannazaro, "Ceramica invetriata" (Glazed ceramics), in La ceramica e i materiali di età romana. Classi, produzioni, commerci e consume (Roman ceramics and materials. Classes, productions, trade and consumption), Interdisciplinary School of Archaeological Methodologies 2, ed. Daniela Gandolfi (Bordighera: Instituto Internazionale di Studi Luguri, 2003); Bárbara Porcari, Alessia Contino, Federica Luccerini, Valentina Mastrodonato, and Simona Sclocchi, "Scarti di produzione di cerámica invetriata dallo scavo del Nuevo Mercato Testaccio a Roma" (Glazed ceramics from the excavation of the Nuevo Mercato Testaccio in Rome), Rei Cretariae Romanae Fautorum, RCRF, Acta 41 (Bonn: RCRF, 2010); Morillo, "La cerámica vidriada romana en Hispania," 406-407.

31. Hatcher, et al., "Chemical classification and provenance of some glazed ceramics"; Tekkök et al., "The importance of archaometric analysis on ceramics."

32. Alberto López Mullor, "Cerámica vidriada romana" (Roman glazed pottery), in Butlletí Informatiu de l'Institut de Prehistòria I Arqueologia de la Diputació Provincial de Barcelona (Informative bulletin of the Institute of Prehistory and Archeology of the Diputacion Provincial de Barcelona) (1978): 27-28; Juan Ángel Paz Peralta, "La producción de cerámica vidriada" (The production of glazed ceramics), in Cerámicas hispanorromanas. Un estado de la cuestión (Spanish-Roman ceramics. A state of affairs), ed. Dario Bernal and Albert Ribera (Cádiz: Universidad de Cádiz, 2008); Morillo, "La cerámica vidriada romana en Hispania."

33. Morillo, 414-415; Morillo, et al., "Cerámica vidriada romana." 
Like the amphorae, the glazed pottery found in the Roman camps of León come from different Early Imperial contexts, from the Augustan period up to the end of the first century AD. The chrono-typological study has identified various forms (skyphoi, kantharoi, chalices, pots and jars), attributable to different manufacturing centres, namely in Asia Minor, Campania, Lazio and, possibly, Hispania. ${ }^{34}$

As might be expected, most of the specimens came from the occupation of the Late Augustan and Julio-Claudian camps of the Legio VI Victrix, which diminish substantially as from the establishment of the Legio VII Gemina in 74 AD.

The recent archaeometric analyses have confirmed the attribution of six specimens to Eastern Mediterranean, specifically from Asia Minor. ${ }^{35}$

The León vessels, skyphoi and chalices, correspond to the types mostly produced in the Asia Minor region, accounting for about $60 \%$ of the findings. ${ }^{36}$ There are several skyphoi of the Hochuli-Gysel type (Ringhenkelskyphos II), which López Mullor attributes to variant $\mathrm{II}^{37}$ characterised by their annular base, fronted annular handles separated by volutes, a low, wide body and rectilinear rim marked by a frame. These forms are inspired by silver and bronze specimens. ${ }^{38}$ Chalices with a flat, rectilinear or slightly sloping rim are also documented, which show a very marked carina and below the characteristic curvature of the high-stemmed chalices of hemispherical body, with or without handles. As in the previous form, these chalices are contemplated in the HochuliGysel typology, specifically in their type 6 (=López Mullor's Form V). ${ }^{39}$

All of them present yellow and white clays with green glazing on the outside and yellowish to the inside. Only the no. 4 presents yellow glazed in both sides.

As is usual in these productions, the León specimens are carefully decorated. One of these (no. 1) presents a wall decorated with a wreath of vine leaves and bunches of grapes, a well-known motif in these productions. ${ }^{40}$ No. 2 also presents a plant motif, consisting of a wreath of ivy leaves and flowers, very frequent in

34. Morillo et al., "Cerámica vidriada romana."

35. Morillo et al.

36. Hochuli-Gysel, Kleinasiatische glasierte Reliefkeramik; Hochuli-Gysel, "La cerámique à glaçure plombifère d'Asie Mineure."

37. López Mullor, "Cerámica vidriada romana"; López Mullor, "De nuevo sobre la cerámica vidriada de Mataró" (Again on the glazed pottery of Mataró), in Quaderns de Prehistoria I Arqueologia de Mataró i el Maresme (Notebooks of Prehistory and Archeology of Mataró and the Maresme) (1980): 11-12; López Mullor, "Notas para una clasificación de los tipos más frecuentes de cerámica vidriada romana en Cataluña" (Notes for a classification of the most frequent types of Roman glazed ceramics in Catalonia), Ampurias 43 (1981): 201-216.

38. Morillo et al., "Cerámica vidriada romana," 1-4.

39. Morillo et al., 5-6.

40. Hochuli-Gysel, Kleinasiatische glasierte Reliefkeramik, 87-89: plate 33, plate 46, T, 37; plate 51, T. 123, 134 and 160, plate 54, T. 188 
the decorative motifs typified..$^{41}$ Extremely interesting are no. 3 and no. 4 which feature figurative motifs (Figure 8).
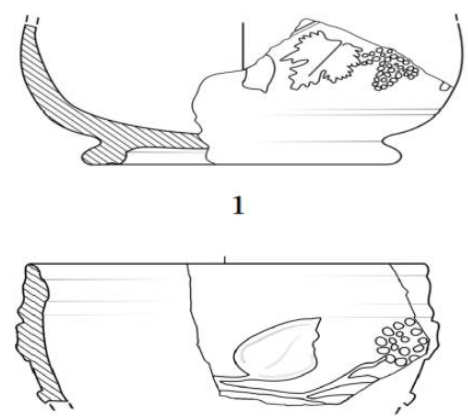

2

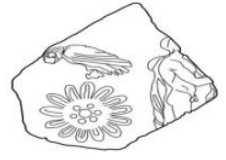

3

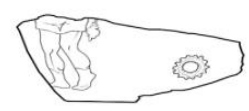

Figure 8. Eastern Roman Glazed Ware from Late Augustan and Julio-Claudian Camps of the Legio VI Victrix in León ( $\left.n^{-0} 1-4\right)$

Although they are different items, they present the same iconographic cycle: Orestes' trial (Iudicium Orestis). In this theme, the hero appears in the company of Athena and an Erinys (or Fury) alluding to the moment in which the tutelary deity inclines the scale in favour of Orestes during the trial celebrated in the Areopagus, thus forgiving the matricide. ${ }^{42}$ It is possible that this motif is inspired by metal specimens, such as the silver kantharus known as Coppa Corsini, from Antium (Anzio), and presently preserved in the Corsini Palace in Rome (Figure 9). ${ }^{43}$

No. 3 bears a naked figure with a chlamys over the shoulders, probably representing Orestes himself, accompanied by a landed eagle (whose wings are closed) and a rosette (Figure 10).

41. Hochuli-Gysel, 83 and 86, plates 32 and 64 .

42. Hochuli-Gysel, 66-67: plate 41, motifs 84, 42, 91 and 86, plate 54, T. 176 and T. 48.

43. LIMC, Aletes $3=$ Athena/Minerva 389=Erigone II 5=Erinys 75=Elektra I 76. 


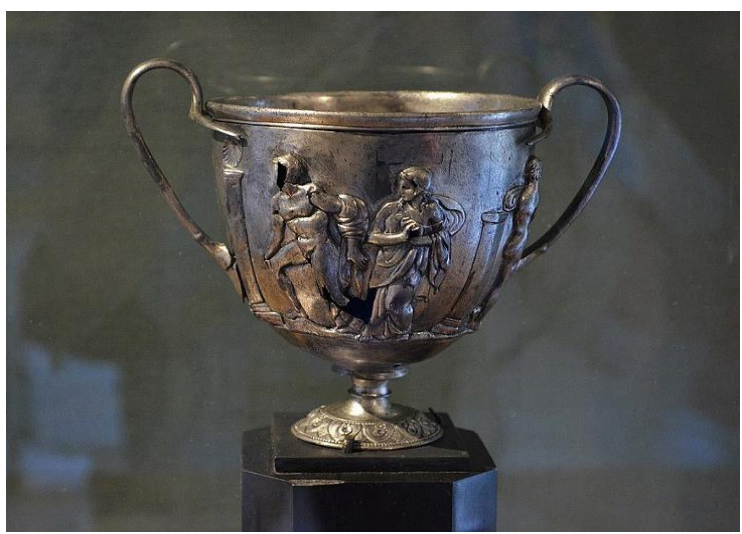

Figure 9. Silver Kantharus known as Coppa Corsini, from Antium (Anzio) Source: https://bit.ly/2JkRRUs.

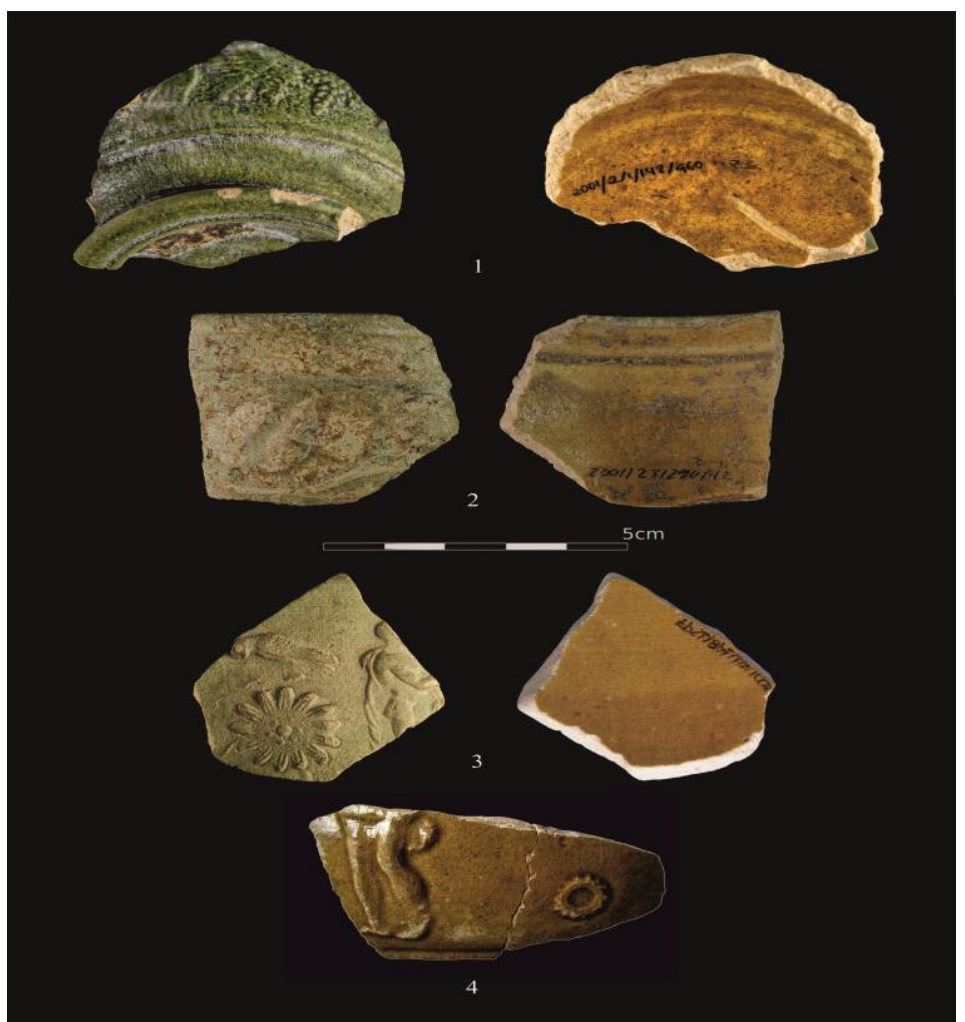

Figure 10. Roman Glazed Pottery from Asia Minor found in León Source: Morillo, "La cerámica vidriada romana en Hispania."

No. 4 illustrates another part of the scene, in this case an Erinys or Fury that carries an inverted torch, next to a small rosette. Both decorations are characteristic of the Tarsus workshops, the only ones which according to Hochuli-Gysel documents this motif (Figure 10).

No. 5 and 6 correspond to chalices, of which only no. 5 preserves its plant decoration ${ }^{44}$ (Figure 11).

44. Morillo et al., "Cerámica vidriada romana." 


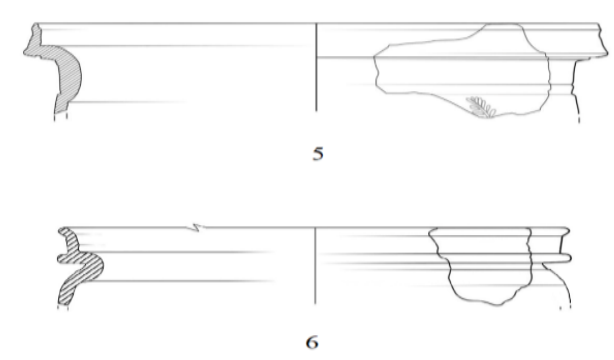

Figure 11. Eastern Roman Glazed Ware from Julio-Claudian Camps of the Legio VI Victrix $\left(n^{\underline{0}} 5-6\right)$

The analysis of several pieces confirmed their Asia Minor provenance and their relation with the productions of Izmir or Klazomenai. ${ }^{45}$

\section{Conclusion}

The presence of a high quantity of imported Roman pottery, especially Italic terra sigillata, thin walls and oil lamps, from the first occupation of the first camp of the Legio VI Victrix, established at the turn of the millennium, and which was replaced around $15 \mathrm{AD}$ by a new, more stable fortification that remained until about $74 \mathrm{AD}$, testify to the constant supply of products from distant parts of the Empire.

In this context, the presence of Eastern Mediterranean amphorae containing high-quality wines during the Late Augustan-Tiberian and Julio-Claudian occupation, bear witness to well-defined chronological limits at León due to sequenced records of the materials (Figure 12). ${ }^{46}$

45. Morillo et al., no. 1 and no. 5.

46. Morillo and García Marcos, "Legio (León): cronologías estratigráficas"; Morillo, "Cerámica romana en el campamento de León." 


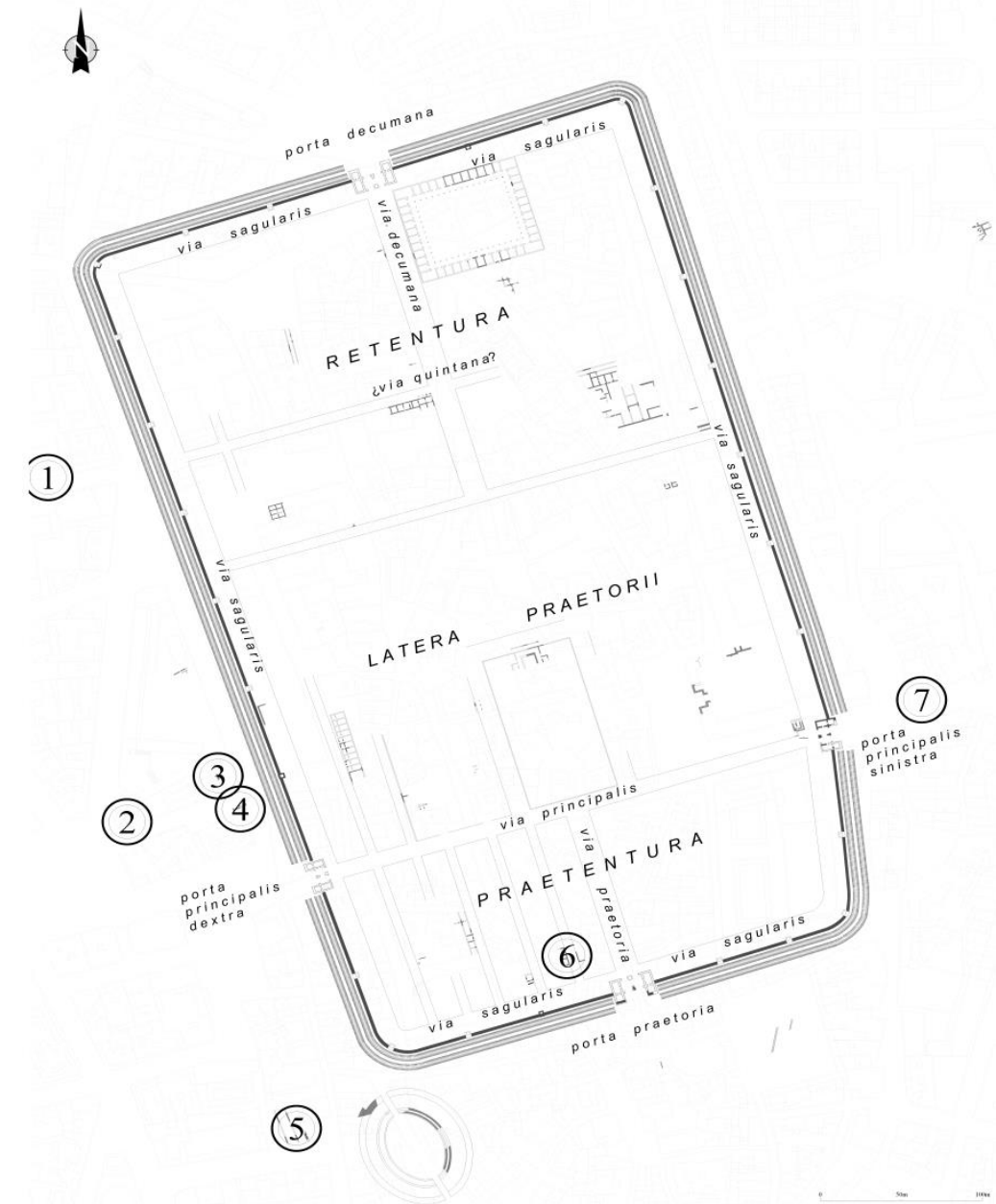

Figure 12. Main archaeological Sectors of the Camps of León with Finds of Eastern Mediterranean Amphorae and Roman Glazed Pottery Related to the Legionary Camp of Legio VII Gemina: 1. Calle La Torre no 9; 2. Calle Pilotos Regueral no 9 (Banco Herrero); 3. Casa Pallarés; 4. Edificio Botines; 5. Calle General Lafuente clv calle La Rúa; 6. Iglesia de Palat del Rey; 7. San Pedro; 8. Calle San Francisco $n^{-} 13, \mathrm{cl}$ calle Hospicio; 9. Puente Castro (2,2 km southwest). ${ }^{47}$

The presence of these products in western markets provoked the emergence of manufacturing centres that were gradually imitating and replacing them. In spite of the low representativeness of these products to the west, their presence in León is not surprising, possibly associated to consumption restricted to the officers, stronghold of the Roman elite at the beginning of the Empire. The maintenance of social customs and culinary habits with expensive imported products was part of non-verbal communication, as a way of showing the superiority of the ruling classes, and as a way of maintaining their

47. Morillo et al., "Cerámica vidriada romana." 
identity, status, and different lifestyle. Imported products reinforce this distinction and group ties..$^{48}$

These vessels were accompanied during their trip to the West by the glazed pottery from Asia Minor, a prestigious element linked precisely to the consumption of wine, which seems destined to a lower social stratum, to that of the non-commissioned officers, who tried to imitate the customs of the elite, but who could not afford metal tableware.

This consumption profile can be found in other military camps of the Augustan and Julio-Claudian period, such as in Fréjus, ${ }^{49}$ where the same trend of maintaining a reduced but continuous supply of eastern amphorae and glazed pottery is documented.

Noteworthy in this León set are the glazed specimens with the theme of Orestes' trial, a motif found on contemporaneous silver tableware, to which Pliny made reference. ${ }^{50} \mathrm{~A}$ number of conflicts on the divine and human planes can be seen in this scene. This final episode in Orestes' tragic story illustrates the two opposing forces in the new Rome of Augustus: according to the Roman tradition, Augustus deposited Orestes' ashes in the Roman Forum, near the temple of Concordia, on occasion of the restoration of the Temple of Saturn. ${ }^{51}$ Virgil indicates that the ashes of the hero are one of the seven talismans that guarantee the permanence of Rome.52 The intention was clear: to associate the figure of Orestes with the ascension of the young emperor to the principality. In Koch Piettre's study, ${ }^{53}$ the allegorical association with the figure of Orestes intended to transmit the filial love of the princeps to his adoptive father, Julius Caesar, and justify the excesses committed during the civil war and the conquest of pax Augusta (in this case using the metaphorical transformation of the Furies into pacified Erinyes). As in the case of Orestes, the vindictive excesses of the young princeps would be justified by the authority of Apollo, the great god of Delphi, and his sister Artemis; the pacifying action would be the responsibility of the goddess Athena

48. Morillo and Morais, Ánforas de los campamentos romanos de León.

49. Sylvie Saulnier, "Céramiques à glaçure plombifère" (Ceramics with lead glaze), in Le Camp de la Flotte d'Agrippa a Fréjus. Les fouilles du quartier de Villeneuve (The Agrippa Fleet Camp at Frejus. The excavations of the Villeneuve district), ed. Chistian Goudineau and Daniel Brentchaloff (Paris: éd. Errance, 2009), 405-407.

50. Nat. Hist. XXXIII, 156.

51. Renee Koch Piettre, "Oreste, un héros grec dans la religion romaine" (Oreste, a Greek hero in the Roman religion), in Manières de penser dans l'Antiquité méditerranéenne et orientale. Mélanges offerts à Francis Schmidt par ses élèves, ses collègues et ses amis (Ways of thinking in Mediterranean and Eastern Antiquity. Mixes offered to Francis Schmidt by his students, colleagues and friends), ed. Chisrophe Batsch and Madalina Vârtejanu-Joubert (Leiden-Boston: Brill, 2009), 241-242.

52. Aeneid VII, 188.

53. Koch Piettre, "Oreste, un héros grec dans la religion romaine," 256-259. 
transforming a moment of crisis into a Golden Age. Rome thus assumed the role of Athens, which, as a sign of civilisation, appeased the gods.

\section{Bibliography}

Biagini, Marco. "Ceramica invetriata campano-laziale in Liguria" (Glazed Campania-Lazio ceramics in Liguria). Rivista Studi Liguri LVIII (1992): 131-146.

Carreras Monfort, César, and Rui Morais. "Las ánforas de Lucus Augusti (Lugo)" [The amphorae of Lucus Augusti (Lugo)]. In Ánforas romanas de Lugo (Roman amphorae of Lugo), edited by César Carreras Monfort, Rui Morais, and Enrique González Fernández. Lugo: Concello de Lugo, 2011.

Carreras Monfort, César, and Piero Berni Millet. "Anforas" (Amphorae). In Astorga IV. Lucernas y ánforas (Astorga IV. Lucernas and amphorae), edited by $\mathrm{M}^{\mathrm{a}}$ Teresa Amaré. León: Universidad de León, 2003.

Desbat, André. "Les productions précoces de Céramiques à glaçure plombifère de la Vallée du Rhôhne" (The early productions of ceramics with lead glaze of the Rhôhne Valley). Rei Cretariae Romanae Fautorum, RCRF, Acta 34. Székesfehérvar: RCRF, 1995.

. "Céramiques romaines à glaçure plombifère de Lyon et de Vienne" (Roman ceramics with lead glaze of Lyon and Vienne). SFECAG. Congress Proceedings of Toulouse. Marseille: SFECAG, 1986.

. "Céramiques romaines à glaçure plombifère des fouilles de Lyon (Hauts-de-SaintJust, Rue des Farges, La Solitude)" [Roman ceramics with lead glaze of the excavations of Lyon (Hauts-de-Saint-Just, Rue des Farges, La Solitude)]. Figlina 7 (1986): 105-124.

di Gioia, Emanuela. La ceramica invetriata in area vesubiana (Glazed ceramic in the Vesubian area). Roma: L'Erma di Bretschneider, 2006.

Gohier, Pauline. Les cerámiques à glaçure plombifere antiques en Gaule méridionale et dans la vallée du Rhône (Ier siècle av. J. C. - IIIe siècle apr. J. -C.) [The ceramics with ancient lead glaze in southern Gaul and in the Rhone Valley (1st century BC - $3^{\text {rd }}$ century AD)]. Archeology Roman History, 40. Drémil Lafage: M. Mergoil Editions, 2018.

Gohier, Pauline, Claudio Capelli, and Roberto Cabella. "Les cerámiques à glaçure plombifère en Gaule Méridionale: nouvelles données archéologiques et archéometriques" (The ceramics with lead glaze in southern Gaul: new archaeological and archaeological data). SFECAG. Proceedings of the Autumn Congress. Marseille: SFECAG, 2016.

Gabelmann, Heinrich. "Zur hellenistisch-römischen Bleiglasurkeramik in Kleinasien" (On the Hellenistic-Roman lead glaze ceramic in Asia Minor). Journal of Deustchen archäoliguschen Instituts 89 (1974): 260-307.

García Marcos, Victorino. "Novedades acerca de los campamentos romanos de León" (News about the Roman camps of León). In Arqueología Militar Romana en Hispania (Roman Military Archeology in Hispania). Annexes of Gladius 5, coordinated by Ángel Morillo. Madrid: Polifemo y CSIC, 2002.

García Marcos, Victorino, Rosalía Durán Cabello, and Ángel Morillo. "La muralla tetrárquica de Legio: aproximación al conocimiento de su sistema constructivo" (The 
Tetrarchic wall of Legio: approach to the knowledge of its construction system). In Murallas de Ciudades Romanas en el Occidente del Imperio (Walls of Roman Cities in the Western Empire), edited by Antonio Rodríguez Colmenero and Isabel Rodá. Lugo: Diputación Provincial de Lugo, 2007.

Goldman, Hetty. Excavations at Gözlü Kule, Tarsus, I, The Hellenistic and Roman Period. Princeton: Princeton Press, 1950.

Hatcher, Helen, Alexander Kaczmarczyk, Agnès Scherer, and Robin Symonds. "Chemical classification and provenance of some glazed ceramics." American Journal of Archaeology 98, no. 3 (1994): 431-456.

Hochuli-Gysel, Anne. "La cerámique à glaçure plombifère d'Asie Mineure e du basin Mediterranéan oriental (du Ier s. av. J.-C. au Ier s. ap. J.-C.)" [The lead-glazed ceramics of Asia Minor and Eastern Mediterranean Basin (1st century BC to 1st century AD)]. In Céramiques hellénistiques et romaines: Productions et diffusion en Méditerranée orientale (Chypre, Égypte et côte syro-palestinienne) [Hellenistic and Roman ceramics: Productions and diffusion in the Eastern Mediterranean (Cyprus, Egypt and the Syrian-Palestinian coast)], edited by Francine Blondé, Pascal Ballet, and Jean-François Salles. Lyon: Travaux de la Maison de l'Orient 35, 2002.

_. Kleinasiatische glasierte Reliefkeramik (50 v. Chr. Bis 50 n. Chr.) und ihre oberitalischen Nachamungen [Asia Minor glazed relief ceramics (50 BC to $50 \mathrm{AD}$ ) and their Upper Italian aftermath]. Acta Berniensia 7. Bern: Verlag Stämpeli and CIE AG, 1977.

Jones, Frances Folin. Excavations at Gözlü Kule, Tarsus I. The Hellenistic and Roman periods. Princeton: Princeton Press, 1950.

"Rhosica Vasa." American Journal of Archaeology 49 no. 1 (1945): 45-51.

Koch Piettre, Renee. "Oreste, un héros grec dans la religion romaine" (Oreste, a Greek hero in the Roman religion). In Manières de penser dans l'Antiquité méditerranéenne et orientale. Mélanges offerts à Francis Schmidt par ses élèves, ses collègues et ses amis (Ways of thinking in Mediterranean and Eastern Antiquity. Mixes offered to Francis Schmidt by his students, colleagues and friends), edited by Chisrophe Batsch and Madalina VârtejanuJoubert. Leiden-Boston: Brill, 2009.

López Mullor, Alberto. "Notas para una clasificación de los tipos más frecuentes de cerámica vidriada romana en Cataluña" (Notes for a classification of the most frequent types of Roman glazed ceramics in Catalonia). Ampurias 43 (1981): 201-216.

—. "De nuevo sobre la cerámica vidriada de Mataró" (Again on the glazed pottery of Mataró). In Quaderns de Prehistoria I Arqueologia de Mataró i el Maresme (Notebooks of Prehistory and Archeology of Mataró and the Maresme). 1980.

_. "Cerámica vidriada romana" (Roman glazed pottery). In Butlletí Informatiu de l'Institut de Prehistòria I Arqueologia de la Diputació Provincial de Barcelona (Informative bulletin of the Institute of Prehistory and Archeology of the Diputación Provincial de Barcelona). 1978.

Lusuardi Siena, Silvia, and Marco Sannazaro. "Ceramica invetriata" (Glazed ceramics). In Scavi MM3. Ricerche di archeologia urbana a Milano durante la costruzione della linea 3 della Metropolitana (MM3 excavation. Urban archeology research in Milan during the construction of the Metro line 3). Milano: ET, 1991.

Maccabruni, Claudia. "Cerámica con invetriatura al piombo" (Cerámica with lead glaze). In Céramiques hellénistiques et romaines II (Hellenistic and Roman ceramics II), edited by P. Léveque and Jean-Paul Morel. Paris: CNRS, 1987.

Martin, Archer. "Central Italian lead-glazed ware." Rei Cretariae Romanae Fautorum, RCRF, Acta 34. Székesfehérvar: RCRF, 1997. 
"La ceramica invetriata romana: la testimonianza dell'area NE delle terme del Nuotatore ad Ostia" (The Roman glazed ceramic: the testimony of the NE area of the Nuotatore spa in Ostia). In La ceramica invetriata tardoantica e altomedievale in Italia (Late antique and early medieval glazed pottery in Italy), edited by Lidia Paroli. Firenze: All'Insegna del Giglio, 1992.

Morais, Rui, and Ángel Morillo. "La terra sigillata hispánica altoimperial en los contextos de consumo del noroeste peninsular: Bracara Augusta y Legio" (The high-imperial Hispanic sigillata terra in the consumption contexts of the peninsular northwest: Bracara Augusta and Legio). In Terra sigillata Hispánica. 50 años de investigaciones (Terra sigillata Hispanic. 50 years of research), edited by Maria Isabel Fernández García, Pablo Ruiz Montes, and M ${ }^{\mathrm{a}}$ Victoria Peinado. Roma: Quasar, 2015.

Morillo, Ángel. "La cerámica vidriada romana en Hispania" (Roman glazed pottery in Hispania). In Manual de Cerámica romana III. Cerámicas romanas de época altoimperial en Hispania. Cerámica común de mesa, cocina y almacenaje. Imitaciones hispanas de producciones romanas universales (Roman Ceramics Manual III. Roman ceramics from the high imperial era in Hispania. Common ceramic table, kitchen and storage. Hispanic imitations of universal Roman productions), edited by Carmen Fernández Ochoa, Ángel Morillo, and Mar Zarzalejos. Alcalá de Henares: MNAR, 2017.

"Cerámica romana en el campamento de León durante el Alto Imperio: importación vs. Producción local" (Roman pottery in the Leon camp during the High Empire: import vs. local production). In Cerámicas de época romana en el Norte de Hispania y en Aquitania. Producción, comercio y consumo entre el Duero y el Garona (Roman era ceramics in northern Hispania and in Aquitaine. Production, trade and consumption between the Duero and the Garonne), edited by Ana Martínez Salcedo, Milagros Esteban, and Enrique Alcorta. Madrid: La Ergástula, 2015.

"Investigación científica y arqueología urbana en la ciudad de León" (Scientific research and urban archeology in the city of León). In Hispaniae urbes. Investigaciones arqueológicas en ciudades históricas (Hispaniae urbes. Archaeological research in historic cities), edited by José Beltrán and Oliva Rodríguez. Sevilla: Univ. Sevilla, 2012.

"Abastecimiento y producción local en los campamentos romanos de la región septentrional de la península ibérica" (Local supply and production in the Roman camps of the northern region of the Iberian Peninsula). In Arqueología Militar Romana en Hispania: Producción y abastecimiento en el ámbito militar (Roman Military Archeology in Hispania: Production and supply in the military field), edited by Ángel Morillo. León: Universidad de León, 2006.

Morillo, Ángel, and Victorino García Marcos. "Legio (León). Introducción histórica y arqueológica" [Legio (Leon). Historical and archaeological introduction]. In Los campamentos romanos en Hispania (27 a. C.-192 d. C.). El abastecimiento de moneda [The Roman camps in Hispania (27 BC-192 AD). Currency supply]. Annexes of Gladius 9, coordinated by Ma Paz García-Bellido. Madrid: CSIC and Polifemo, 2006.

"Legio (León): cronologías estratigráficas" [Legio (León): stratigraphic chronologies]. In Los campamentos romanos en Hispania (27 a. C.-192 d. C.). El abastecimiento de moneda [The Roman camps in Hispania (27 BC-192 AD). Currency supply]. Annexes of Gladius 9, coordinated by Mํㅗ Paz García-Bellido. Madrid: CSIC and Polifemo, 2006.

"The defensive system of the legionary fortress of VII gemina at León (Spain): The porta principalis sinistra." In Limes XIX. Proceedings of the XIXth International Congress of Roman Frontier Studies, edited by Zsolt Visy. Pécs: University of Pécs, 2005. 
. "Importaciones itálicas en los campamentos romanos del norte de Hispania durante el periodo augusteo y julioclaudio" (Italic imports in the Roman camps of northern Hispania during the August and July claudio periods). In Rei Cretariae Romanae Fautores. Acta 38. Abingdon: RCRF, 2003.

Morillo, Ángel, and Rui Morais. Ánforas de los campamentos romanos de León. Un modelo de abastecimiento militar entre el periodo augusteo y los inicios del siglo II d. C. (Amphoras of the Roman camps of León. A military supply model between the August period and the beginning of the second century AD. C). Annexes Spanish Archive of Archeology. Madrid: CSIC, in press.

Morillo, Ángel, and Rosalía Durán Cabello. "La puerta meridional del recinto amurallado de la ciudad de León (siglos I-XIII). Análisis estratigráfico e interpretativo de una nueva evidencia constructiva" [The southern gate of the walled enclosure of the city of León (1 $1^{\text {st }} 13^{\text {th }}$ centuries). Stratigraphic and interpretive analysis of new constructive evidence]. Arqueología de la Arquitectura 14 (2017): 1-26.

Morillo, Ángel, Rui Morais, and Rosalía Durán Cabello. "Cerámica vidriada romana en los contextos altoimperiales del campamento de León (España)" [Roman glazed ceramics in the high imperial contexts of the León camp (Spain)]. Saguntum [in press].

Morillo, Ángel, Rui Morais, and Rosario García Giménez. "Análisis mineralógico, físico y químico de ánforas tipo Dressel 28 y jarras en cerámica común del campamento romano de León" (Mineralogical, physical and chemical analysis of Dressel 28 amphorae and common ceramic jugs from the Roman camp of León). In Archaeoanalytics. Chromatography and DNA analysis in Archaeology, edited by Rui Morais, Cesar Oliveira, and Ángel Morillo. Esponsende: Esposende City Council, 2015.

Paz Peralta, Juan Ángel. "La producción de cerámica vidriada" (The production of glazed ceramics). In Cerámicas hispanorromanas. Un estado de la cuestión (Spanish-Roman ceramics. A state of affairs), edited by Dario Bernal and Albert Ribera. Cádiz: Universidad de Cádiz, 2008.

Pircio Biroli Stefanelli, Lucia. (Ed.). I Bronzo dei romani. Arredo e suppellettile. Il Metallo: Mito e fortuna nel mondo antico (Bronze of the Romans. Furnishings and furnishings. The Metal: Myth and luck in the ancient world). Roma: L'Erma d'Bretshcneider, 2008.

_. (Ed.). L'argento dei romani. Vasellame da tavola e d'apparato (The silver of the Romans. Tableware and equipment). Roma: L'Erma d'Bretshoneider, 1991.

Porcari, Bárbara, Alessia Contino, Federica Luccerini, Valentina Mastrodonato, and Simona Sclocchi. "Scarti di produzione di cerámica invetriata dallo scavo del Nuevo Mercato Testaccio a Roma" (Glazed ceramics from the excavation of the Nuevo Mercato Testaccio in Rome). Rei Cretariae Romanae Fautorum, RCRF, Acta 41. Bonn: RCRF, 2010.

Sannazaro, Marco. "Ceramica invetriata" (Glazed ceramics). In La ceramica e i materiali di età romana. Classi, produzioni, commerci e consume (Roman ceramics and materials. Classes, productions, trade and consumption). Interdisciplinary School of Archaeological Methodologies 2, edited by Daniela Gandolfi. Bordighera: Instituto Internazionale di Studi Luguri, 2003.

Saulnier, Sylvie. "Céramiques à glaçure plombifère" (Ceramics with lead glaze). In Le Camp de la Flotte d'Agrippa a Fréjus. Les fouilles du quartier de Villeneuve (The Agrippa Fleet Camp at Frejus. The excavations of the Villeneuve district), edited by Chistian Goudineau and Daniel Brentchaloff. Paris: éd. Errance, 2009. 
Vol. 6, No. $1 \quad$ Morillo Cerdán et al.: Imports from the Eastern Mediterranean...

Soricelli, Gianluca. "Osservazioni intorno ad un crátere in cerámica invetriata da Pompei" (Observations around a crátere in cerámica glazed from Pompeii). Rivista Studi Pompeiani 2 (1988): 248-254.

Tekkök, Billur, Ali Akyol, Yusuf Kadioglu, and Sahinde Demirci. "The importance of archaometric analysis on ceramics from archaeological excavations: the example of Early Roman glazed ware from Tarsus and Troia." In Seres 09. International Ceramic, Glass, Porcelain Enamel, Glaze and Pigment Congress. Eskisehir: Anadolu University, 2009.

Vertet, Hugues. "Recherches sur les glaçures plombifères fabriquées dans le centre de la Gaule" (Research on lead glazes made in the center of Gaul). SFECAG. Congress Proceedings of Toulouse. Marseille, SFECAG, 1986. 